Izvirni znanstveni članek Original scientific paper (1.01) Besedilo prejeto Received: 21. 10. 2019; Sprejeto Accepted: 4. 11. 2019

UDK UDC: 27-67

27-36:929sv. Frančišek As. 929Zvizdović A.

DOI: https://doi.org/10.34291/Edinost/74/02/Babic

\author{
Mile Babić
}

\title{
Susreti svetoga Franje Asiškoga i fra Anđela Zvizdovića sa sultanima
}

\author{
Meetings of St. Francis of Assisi and of Fr. \\ Andeo Zvizdović with Sultans
}

\begin{abstract}
Sažetak: Susreti sv. Franje Asiškoga sa sultanom Malikom al-Kamilom 1219. u Egiptu (u gradu Damietti) za vrijeme Pete križarske vojne i fra Anđela Zvizdovića sa sultanom Mehmedom II. el-Fatihom (Osvajačem) u Bosni na polju Milodraž 1463. nakon pada Bosanskoga Kraljevstva označuju prijelaz iz paradigme nasilja u paradigmu nenasilja. To je susret dvojice nosilaca onodobne najveće svjetske moći s dvojicom franjevaca koji su nosioci najveće svjetske nemoći, tj. ljubavi kao samoponiznosti (kenosis). Vojna i svaka druga moć uvećavaju se tako što njezini nosioci stalno pobjeđuju svoje neprijatelje. To je logika neprijateljskoga pristupa onima koji se ne podređuju toj moći. Pobjeđivanjem moć stalno raste i tako sebe stalno uzvisuje. Moć može rasti samo ako pred sobom ima neprijatelja. Nemoć, tj. ljubav kao samoponiznost odnosi se prema svima kao prijateljima i tako samu sebe ponizuje. Ona se prema neprijateljima odnosi kao prema prijateljima. Tako ljubav kao samoponiznost može obratiti svaku vojnu i drugu moć, ali ne može obratiti (promijeniti) svetu moć, tj. moć koja samu sebe apsolutizira. Fra Anđeo Zvizdović ostaje vjeran evanđeoskoj logici sv. Franje Asiškoga, tj. logici dobrote i samoponiznosti, dakle, ostaje vjeran logičkoj formi (L. Wittgenstein) Evanđelja. Iz toga slijedi da su pobjednici i pobijeđeni jednako udaljeni od svoje slobode.
\end{abstract}

Ključne riječi: samoponiženje, samouzvisivanje, logika dobrote, moć dobrote, sveta moć

Abstract: Two meetings: of St Francis of Assisi with sultan Malik al-Kamil in Damietta in Egypt
1219 during the Fifth Crusade, and of Fr. Andeo Zvizdovic with sultan Mehmed II el-Fatih
(Conqueror) on the field Milodraż in Bosnia 1463 after the fall of Bosnian Kingdom, mark
out the transition from violence paradigm to nonviolence paradigm. It was a meeting of two
holders of world power with two friars - holders of world's highest powerlessness, i.e. love
as self-humility (kenosis). Military and every other power are amplified by victories of its
holders over their enemies. It is a logical approach to those who don't submit to their power.
The power is constantly growing and self-exalting by victories. The power needs enemies
for it to enhance. Powerlessness, such as self-humility, addresses everyone as a friend, the-
reby humbling itself. Powerlessness treats enemies as friends. So, love as self-humility can
convert each military and any other power, but it can't convert (change) holy power, i.e.
the power absolutizing itself. Fr. Anđeo Zvizdovic remains faithful to the logic of St Francis
of Assisi, i.e. to the logic of goodness and self-humility, consequently he persists in logical 
form (L. Wittgenstein) of Gospel. Hence, the conquerors and the conquered are equally far from their freedom.

Key words: self-humility, self-exalting, logic of goodness, power of goodness, holy power

\section{Uvod}

U ovom radu želim pokazati, prvenstveno na temelju Spisa svetoga Franje, što je pokrenulo sv. Franju na susret sa sultanom Malikom al-Kamilom u Egiptu 1219. za vrijeme Pete križarske vojne i što je pokrenulo fra Anđela Zvizdovića na susret sa sultanom Mehmedom II. el-Fatihom (Osvajačem) 1463. u Bosni. Zatim ću upozoriti da je ono poimanje Krista koje je pokrenulo sv. Franju na susret sa sultanom također pokrenulo i kustoda bosanske Franjevačke kustodije fra Anđela Zvizdovića. Duh bosanskih franjevaca, osobito fra Anđela, najbolje se zrcali u djelu fra Matije Divkovića, prvoga pisca u Bosni na narodnom jeziku, točnije rečeno, u Divkovićevoj kristologiji. Oba su, dakle, susreta motivirana kristološki i soteriološki. U prvi, dakle, plan stavljam Spise svetoga Franje, ono što je Franjo sam mislio, govorio i činio, a zatim ono što su o njemu rekli franciskanolozi, istraživači i crkveni dokumenti. To zovemo hermeneutičkim pristupom. Temeljno mjerilo kojim mjerimo sv. Franju, kao i sve kršćane, jest Isus Krist, pa je pristup temi utoliko kristološki.

Pritom uzimam u obzir što su o sv. Franji, o njegovu životu i djelu, pisali istaknuti povjesničari srednjega vijeka: Raoul Manselli (2011), Jacques Le Goff (2010) i Chiara Frugoni (2001). Strogo povijesnom metodom oni su pokazali po čemu je sv. Franjo novi čovjek i začetnik novoga svijeta te time i nove paradigme življenja, mišljenja i djelovanja. Nakon toga sažet ću što su o sv. Franji pisali Peter Kammerer, Ekkehart Krippendorff i WolfDieter Narr u zajedničkoj knjizi Franjo Asiški - suvremenik za drukčiju politiku (2008) švicarski franjevac Niklaus Kuster u svojoj knjizi Franjo, buntovnik i svetac (2009) te Richard Rohr u svojoj knjizi Živjeti ljubav. Što je Franjo Asiški učinio drukčije (2015). Ove autore ističem zato što se oni oslanjaju na stroga povijesna istraživanja Franjina života i djelovanja.

Prisutnost i djelotvornost duha sv. Franje među bosanskim franjevcima najdublje su razumjeli genijalni pisci nobelovac Ivo Andrić (1982) i Nikola Šop (1980). Njihovo shvaćanje franjevačkoga djelovanja u Bosni u skladu 
je sa shvaćanjem Matije Divkovića, čija je kristologija u potpunom skladu s kristologijom Franje Asiškoga.

\section{Franjo Asiški kao radikalni reformator kršćanstva}

Važno je istaknuti da je sv. Franjo živio u razdoblju reformskih pokreta, kad reformu Crkve žele i oni na vrhu crkvene hijerarhije i oni na dnu, jasnije rečeno, i klerici i laici. Veliki reformator bio je papa Grgur VII, koji je preminuo 1085, a sv. Franjo je rođen 1182, skoro stotinu godina kasnije. Grgur (papa od 1073) započeo je veliku reformu Crkve kojom je nastojao osloboditi Crkvu od laičke investiture, od toga da svjetovni vladari postavljaju i uvode prelate u crkvene službe, od simonije (kupovanja crkvenih službi) i klerogamije (svećeničke ženidbe). To je bio tzv. spor oko investiture, koji je doveo u sukob papu i njemačkoga cara Henrika IV.

Harold J. Berman u svojoj knjizi Pravo i revolucija (1995) dokazao je svoju temeljnu tezu, koja glasi: razračunavanje između carske i papinske vlasti učinila su nemogućom monolitnu vlast, jer su dovela do diferenciranja svjetovne od duhovne vlasti, tako da je za polovicu stvarnosti nadležna svjetovna vlast, a za drugu polovicu duhovna. Za Bermana su sve revolucija koje su slijedile nakon Grgura samo reformulirale teme grgurovske revolucije. Ta je revolucija oduzela sakralni karakter svjetovnoj vlasti; posrijedi je bila desakralizacija (sekularizacija) političke vlasti. Time se Crkve konstituira kao samostojno i savršeno društvo (societas perfecta), koje se po svome cilju (salus animarum - spasenju duša) razlikuje od države koja je također savršeno društvo čiji je cilj vremenito dobro. Zahvaljujući tom razlikovanju krajem 11. stoljeća postavljeni su temelji za odvajanje politike od religije i države od Crkve.

Važno je istaknuti da su reformu Crkve i države uglavnom željeli svi: i crkvena hijerarhija, i laici, i prosjački redovi (dominikanci i franjevci). Tada se javlja kristocentrična duhovnost, jer se kršćanski život sastoji u praktičnom nasljedovanju Isusa Krista. Jedna od temeljnih promjena koju uvode prosjački redova jest promjena stava prema smrti, koji smrt shvaća kao eshatološku transformaciju (dobivanje punog života, koji nije podložan smrti). Sveti Franjo je radikalan reformator kršćanstva jer se on vraća na kršćanske izvore (reditus ad fontes), na izvornu formu kršćanskoga 
života, a to je vita apostolica et evangelica (na apostolsku i evanđeosku formu života Isusa i njegovih učenika). Kratko rečeno, Isusova forma života je mjerodavna za sve kršćane.

Sociolog Peter Kammerer, politolog Ekkehart Krippendorff i politički filozof Wolf-Dieter Narr u zajedničkoj knjizi Franjo Asiški - suvremenik za drukčiju politiku jasno pokazuju da je sv. Franjo izveo religioznu revoluciju tako što je povratkom mjerodavnoj formi života - a to je forma Isusova života - započeo radikalnu reformu Crkve. U svojoj Oporuci Franjo je rekao: exivi de saeculo (da je izašao iz svijeta nasilja) i da u ovom svijetu nasilja želi uspostaviti novi svijet, svijet mira. On, dakle, nudi alternativu svijetu nasilja: ne bijeg od svijeta, nego alternativu nasilnom svijetu.

Švicarski kapucin Niklaus Kuster u svojoj knjizi Franjo, buntovnik $i$ svetac govori da je Franjo bio buntovnik jer je predano slijedio svoje ideale i tako se odmaknuo od tadašnjih ustaljenih konvencija inicirajući pokret koji će promijeniti svijet. Franjo je istodobno i svetac jer slijedi Isusove stope i otvara se s povjerenjem čovjeku, prirodi i Bogu te traga za dubljim smislom života, koji i pronalazi. U Petoj križarskoj vojni s kršćanskim vojnicima bio je i sv. Franjo. Kad su križari opsjedali egipatski grad Damiettu 1219, Franjo je na vlastitu inicijativu krenuo na razgovor sa sultanom Malikom al-Kamilom, s kojim se sprijateljio. Franji je bilo stalo do mira i njegova miroljubivost očituje se u njegovoj odluci da za vrijeme borbe i bez ičije oružane zaštite i pratnje ode k sultanu na razgovor (»nije se plašio prijeći neprijateljskoj vojsci«; Manselli 2011, 323), jer su za njega muslimani bili braća.

Slijedeći formu Dekaloga, Kuster iz Franjina susreta sa Sultanom izvodi deset načela za dijalog među religijama:

1. Dijalog proizlazi iz molitve, jer svaki uspjeli dijalog nije samo ljudsko djelo, nego i Božji dar. Različita ispovijedanja vjere imaju, dakle, povjerenje u svoju vlastitu molitvu i u molitvu svoga dijaloškoga partnera.

2. Susret sa sultanom inicira Franjo. Njegova hrabrost i sultanova otvorenost omogućuju uspjeh susreta na koji su se odvažili. 
3. Najprije svoju stranu nastoji odvratiti od nasilja. Kad je ismijan i neshvaćen na svojoj strani, pouzdaje se u veću razumnost protivničke strane. Njegov unutarnji mir i njegova nada u nenasilje nadvladavaju protivničke predrasude i omogućuju dijalog između tobožnjih neprijatelja.

4. Franjo doživljava da se njegov partner u razgovoru trudi oko istinite vjere i otkriva da je Božja ljubav prisutna i izvan njegove vlastite religijske zajednice. Povjerenje da je njegov partner povezan s Bogom uspostavlja mostove i sklapa prijateljstva iznad vjerskih granica.

5. Tko hoće i čini dobro drugima, povezuje se s njima po djelima koja su jača od riječi. Franjevci (Minores, Manji) uklapaju se u ljudske poretke drugih kultura, ali sebe razumijevaju kao braću i sestre svakoga stvorenja (1 Pet 2,13) i traže »da služe svakom čovjeku« (Nepotvrđeno pravilo, 16).

6. Franjo zahtijeva da se njegova braća ponašaju iskreno kao kršćani i da to priznaju (Nepotvrdeno pravilo, 16).

7. Susret i dijalog nalaze drugu osnovu onda kad kršćani žive među muslimanima. Franjo ohrabruje svoju braću da žive u istim životnim uvjetima u kojima žive muslimani i da im služe, te da živeći zajedno budu senzibilni za to jesu li i kada su vjerski razgovori dobri.

8. Franjo razlikuje dva oblika navješćivanja vjere: vlastitim životom i djelovanjem te riječima. Prednost daje životu i djelovanju. Tek kad braća upoznaju drugu kulturu i religiju, i samo onda kad jasno osjete da se to Bogu sviđa, neka navijeste evanđelje.

9. Franjo ne djeluje kao individualist. Na put sultanu prati ga brat iluminat. Franjevačko pravilo šalje također braću po dvojicu ili u malim grupama, kako to već piše u Evanđelju, da šire mir i evanđelje u svijetu. Njihovo ponašanje u vlastitom okruženju treba osnažiti ono što oni navješćuju.

10. Franjo je impresioniran svakodnevnom molitvom muslimana i to mu je dalo poticaj za svakodnevni život vlastite religijske zajednice. To zapravo znači kako je za dijalog potrebno čuti i slušati druge te učiti jedni od drugih. 
Poznati američki franjevac Richard Rohr u svojoj knjizi Eager to Love: The Alternative Way of Francis of Assisi, koja je na njemačkome objavljena pod naslovom Die Liebe lieben. Was Franz von Assisi anders machte (Živjeti ljubav. Što je Franjo Asiški učinio drukčije) piše kako je Franjo - po Tomi Čelanskome - bio svjestan dileme koja se sastojala u sljedećem: ako kaže križarima da ne trebaju ratovati i da će bitku izgubiti, oni će ga smatrati ludim; a ako bude šutio, osjećat će grižnju savjesti. U srednjem vijeku vladali su nepovjerenje, strah i mržnja između islama i kršćanstva (možda veći nego danas). Tada se u Europi nije znalo praktički ništa o islamskoj kulturi i religiji. Postojali su samo grozni stereotipi neprijateljstva (Rohr 2015, 158-163).

Križarske su vojne smatrane svetim ratom i uživale su opću potporu. Skoro ih nitko među kršćanima nije osuđivao niti shvaćao da se radi o masovnoj zloporabi moći i Evanđelja. Dotadašnji grijeh simonije prestao je biti grijehom. Tako prestaje biti grijehom i posuđivanje novca uz kamatu te nepoštovanje prema subotnjem miru. Franjo je znao da je sv. Bernhard iz Clairvauxa opravdavao križarske ratove, jer je zajedno s više papa pozvao na kastrofalni Drugi križarski rat. Križari su ratove vodili pod vlastitom zastavom i s mottom često citiranim: Deus vult (Bog hoće [rat]). Usprkos tome, za Franju ti ratovi nisu bili Božja volja, nego su "protiv volje Gospodina ). Neki istraživački - ističe Rohr - postavljaju pitanje: ne postoji li povezanost između križarskih ratova i shizme između Rima i Carigrada (1054). Istočna je Crkva postala našim otuđenim bratom, »neprijateljem«. Neki istraživači tvrde da je sv. Bonaventura u svom životopisu sv. Franje cijelu stvar učinio prihvatljivu Rimu i kršćanskim "patriotima«. Sve je to zapravo bilo smatrano pobožnom legendom. Rohr pošteno priznaje da je i on sam nekada tako mislio.

Franjo napušta svoju vlastitu kulturu na svoju vlastitu štetu da bi potražio sultana, da bi se zaputio u svijet drukčijega, drukčijeg čovjeka, koji je u javnosti slovio kao neprijatelj kršćanskoga svijeta i kršćanske religije. Tri puta je pokušao otići u Svetu Zemlju, ali je uspio tek u trećem pokušaju. Zbog toga je putovao u Egipat kako bi križarskim trupama objasnio da krivo čine sudjelujući u Petoj križarskoj vojni, na koju su pozvali papa Inocent III. i drugi katolički prvaci. Križarima je govorio da ne idu u bitku i najavio im je poraz. Oni su ga ismijali: "Srca im otvrdnuše i ne htjedoše poslušati.« Franjin stav prema neprijateljima, a time i prema islamu, najbolje 
je izražen u 22. poglavlju Nepotvrđenoga pravila u kojem je Franjo pred odlazak u Svetu Zemlju rekao: „Ljubite svoje neprijatelje i činite dobro onima koji vas mrze« (Mt 6,15; Mk 11,26). Gospodin naš Isus Krist, čije stope treba slijediti, nazvao je prijateljem svoga izdajnika i svojevoljno se predao onima koji su ga razapeli. Dakle, prijatelji su naši svi oni, po Franji, koji nam nepravedno nanose patnje i tjeskobe, sramote i nepravde, bolove i mučenja, mučeništvo i smrt: »Te moramo veoma ljubiti jer iz toga što nam nanose imamo život vječni.»

Franjina poniznost, njegovo poštovanje prema drugome, također i prema islamu - po Rohru - omogućilo mu je vjerojatno da skoro tri tjedna provede sa sultanom, pod čijom se zaštitom mogao vratiti križarima ponijevši sa sobom rog kojim se poziva na islamsku molitvu kao sultanov dar. Očito su poštovanje i uvažavanje između Franje i sultana bili uzajamni. Takvo ponašanje prema sultanu i islamu nije postojalo u cijelom srednjem vijeku. Franjo je veoma mudro razlikovao institucionalno zlo i individuuma koji je trpio to zlo. Suosjećao je s vojnicima kao pojedincima, iako je odbacivao rat. Bio je žalostan zbog bitke koja se vodila i smrti vojnika, osobito Španjolaca, zbog njihove »velike nepromišljenosti«.

Svojoj braći u Nepotvrđenom pravilu Franjo objašnjava da se na dva načina može ophoditi sa saracenima (muslimanima). Prvi se način sastoji u tome da se braća ne svađaju i ne prepiru, nego da služe radi Boga svakom ljudskom stvorenju i da se zadovolje time da priznaju svoju vlastitu kršćansku vjeru. To bi značilo da navješćuju kršćansku vjeru vlastitim životom. Druge se način sastoji u tome da navijeste Božju riječ ako se to sviđa Gospodinu. Možda je riječ inšalah Franjo naučio od muslimana. Kod Franje se, kao i kod Isusa, dogodio potpuni obrat svijesti: samo takav novi čovjek može podnijeti društvena zla svoga vremena. Pitanje je može li dualističko (svađalačko) mišljenje našega vremena uopće razumjeti, dopustiti ili podržati takvu radikalnu duhovnost. Rohr misli da se i mi danas nalazimo pred istom dilemom kao nekoć sv. Franjo: ako im kažemo da ne ratuju, smatrat će nas luđacima; a ako šutimo, grist će nas savjest. Ovdje je naprosto riječ o savjesti. 


\section{Samoponiznost kao ljubav}

U ovom poglavlju izložit ću temeljne misli Spisa svetoga Franje na osnovi rada koji sam o njemu objavio (Babić 2019, 79-105) tako što ću dalje razraditi i produbiti osnovne misli Franjine kristologije. Vizija Franje Asiškoga, koja se temelji na Isusovu Evanđelju, naglašava bratstvo i sestrinstvo svih ljudi, ne samo svih ljudi, nego i svih bića, tj. svih Božjih stvorenja u svemiru. Sva su bića u svemiru braća i sestre po stvorenosti. Samo je jedan Stvoritelj, a sva su ostala bića Božja stvorenja. Ta bitna i neukidiva razlika između Stvoritelja i stvorenja temelj je bratstva među ljudima te bratstva i sestrinstva svih Božjih stvorenja. Svi oni koji nisu svjesni razlike između Stvoritelja i njegovih stvorenja pretvaraju vlastitu religiju u idolatriju. Svi današnji religiozni fundamentalizmi nisu ništa drugo nego negacija Boga i pretvaranje Boga u običnoga idola, u lažno božanstvo, u božanstvo smrti, koje ljude poziva na uzajamnu mržnju i na ubijanje. Ove godine, 4. veljače, papa Franjo i veliki imam Ahmad al-Taib u Deklaraciji o ljudskom bratstvu za mir u svijetu i zajednički život pišu da je vjera u jednoga Boga koji je Stvoritelj, koji je stvorio život i sve ljude, temelj bratstva i sestrinstva svih ljudi. Oni ističu da Bog zabranjuje ubijanje ljudi. Zatim kažu: "To tražimo na temelju naše zajedničke vjere u Boga, koji nije stvorio žene i muškarce da budu ubijeni ni da se međusobno sukobljavaju niti da budu zlostavljani ili ponižavani u njihovim životima i okolnostima. Svemogući Bog nema potrebe da ga bilo tko brani i ne želi da se Njegovo ime koristi za teroriziranje ljudi« (Deklaracija, 6. rujna 2019). Treba reći da papa Franjo govori o bratstvu svih ljudi oslanjajući se pritom na sv. Franju. U svom Govoru održanom na ekumenskom i međureligijskom susretu u Sarajevu 2015. Papa je istaknuo da su svi ljudi braća. O tom bratstvu Papa govori i u apostolskoj pobudnici Evangelii gaudium i u enciklici Hvaljen budi.

Svojom vizijom bratstva i sestrinstva svih ljudi i njezinim prakticiranjem Franjo Asiški je ponudio alternativu svijetu mržnje i nasilja u kojem i danas živimo. To je iskazao svojom poznatom rečenicom: Exivi de saeculo (Izašao sam iz svijeta nasilja). Izašao je, dakle, iz svijeta nasilja i počeo stvarati svijet mira. Sv. Franjo - i franjevci koji ga slijede - zastupa spasenje cijeloga svijeta, sveukupnoga Božjega stvorenja. Bog ljubi svoje stvorenje i želi ga spasiti u cjelini. Time sv. Franjo odbacuje ontološki i svaki drugi oblik dualizma. Ovaj je svijet stvorio dobri Bog i sve što je stvoreno dobro je i lijepo i izvor je naše radosti. Taj dualizam do danas proizvodi užas 
u svijetu, jer zastupa stav da nema spasenja za cijelu stvarnost, nego samo za određenu stvarnost i samo za neke ljude. Pitanje zla dualizam je riješio na fundamentalno pogrešan način lociravši zlo u druge. Ako je zlo samo u drugima, onda kad ubiješ druge ti ubijaš zlo i za to ubijanje zla očekuješ nagradu i priznanje. Religiozni fundamentalisti ne vjeruju u Božju svemoć. Oni ne vjeruju da bi Bog mogao uništiti svijet kad bi htio. Tako oni pretvaraju Boga u svoga slugu, tj. u idola, koji opravdava njihovu mržnju i ubijanje.

Koliko je dualističko mišljenje neistinito najbolje se vidi kad proučavamo što povjesničari kažu o vođi križarske vojske kardinalu Pelagiju, a što kažu o sultanu Maliku. Francuski franjevac Gwenolé Jeusset navodi u svojoj knjizi Sveti Franjo i sultan kako Oliver Kölnski u svome pismu Maliku iskazuje svoje poštovanje sultanu i tvrdi da je sultan zaslužio ime Kamil (što znači »savršeni«). Na drugoj strani, na temelju dokumenata Jeusset opisuje aroganciju i nepopustljivost papinskoga legata Pelagija (Jeusset 2008, 93-101).

Za sv. Franju Bog je Ljubav. Budući da je Božja ljubav čista nesebičnost, čista poniznost ("ponizi samog sebe«, Fil 2,7; kenosis), ta se ljubav osobito odnosi na isključene ljude, na one koje mi isključujemo i progonimo. Bog ljubi svoje neprijatelje, a mi smo svi Božji neprijatelji time što smo grešnici. I Bog nas, svoje neprijatelje, ljubi bezuvjetno, posve nesebično i bezgranično. Takvoga Boga, koji je sama Samoponiznost, otkrio nam je Isus Krist. A Isusa Krista Franjo želi nasljedovati do kraja i bez ikakva pridržaja. Zato Franjo želi biti manji od svih ljudi i podložan svakom ljudskom stvorenju. On želi gol nasljedovati gologa Krista (nudus nudum Christum sequi). Po istoj evanđeoskoj logici Franjo se odnosi prema muslimanima; ne želi s njima nikakvu svađu ni prepirku, nego želi maksimalnu poniznost: podložnost svakom ljudskom stvorenju zbog Boga i radi Boga. Bog tako hoće. Najprije, dakle, traži od braće da svjedoče ljubav, a da zatim priznaju tko su, da priznaju svoj kršćanski identitet, to da su kršćani. A kada uvide »da se to Gospodinu sviđa«, Gospodinu koji je sama Ljubav, mogu im navijestiti Božju riječ. Kod Franje nema govora protiv ni logike protiv koja se iscrpljuje u govoru protiv. Franjo djeluje po evanđeoskoj logici dobrote, tako što pozitivno govori o onome o čemu heretici govore negativno. U Nepoturđenom pravilu on kaže: »I kada vidimo ili čujemo 
da ljudi govore ili čine zlo ili Boga hule, tada ćemo mi dobro govoriti i dobro činiti i Boga ljubiti.»

Franjo je religiozni genij, jer ima izravnu relaciju sa Svevišnjim. U svojoj Oporuci on kaže da mu nitko nije pokazao što mora činiti. To mu je sam Svevišnji objavio. Svevišnji mu je objavio da more živjeti po Svetom Evanđelju. Nije mu to, dakle, rekao ni papa ni Crkva, nego Svevišnji. To je Franjina proročka dimenzija, koja se često previđa. Upravo je taj odnos prema Svevišnjemu izvor Franjina mišljenja i djelovanja. Prema Tomi Čelanskome, Franjo je u Damietti govorio križarima da ne idu u bitku, jer mu je to Gospodin rekao: »Gospodin mi je objavo da kršćani, ako toga dana dođe do bitke, neće uspjeti« (1995, 470). Gospodin (Dominus) mu je to objavio i Franjo je odvraćao križare od bitke te ima najavio poraz, ali oni su ga izrugivali: »Srca im otvrdnuše i ne htjedoše poslušati.« I tu je također rečeno da se treba više pokoravati Bogu nego ljudima. Franjo ističe da upamte knezovi ovoga svijeta »da se nije lako boriti protiv Boga, tj. protiv Božje volje«.

U Nepotvrđenom pravilu Franjo nedvosmisleno govori o muslimanima. Braća se mogu ponašati na dva načina. Prvi je način da ne bude nikakve svađe ni prepirke, nikakva govora protiv ni logike protiv, nego ljubav kao samoponiznost, kao poniznost koja ne pozna granica:podložnost svakom ljudskom stvorenju zbog Boga, radi Boga, jer tako Bog hoće. Bog je, naime, prisutan u svakom stvorenju i želi spasiti svako stvorenje. Na latinskome ta rečenica glasi: Sed sint subditi omni humanae creaturae propter Deum (»Neka budu podložni svakom ljudskom stvorenju zbog Boga»), jer to Bog hoće (1 Pet 2,13) i priznaju da su kršćani. To je prvi način: ljubav kao maksimalna samoponiznost i priznanje kršćanskoga identiteta, drukčije rečeno, navješćivanje Evanđelja vlastitim životom, a ne riječima. To zapravo znači da ljubiš muslimana ne očekujući uzvraćanje, potpuno nesebično, onako kako ljubi Bog koji je sama Ljubav. Drugi način ponašanja sastoji se u tome da muslimanima treba navijestiti Božju riječ ako braća uvide da se to sviđa Gospodinu. Prema tome, opet je tu istaknuta Franjina proročka dimenzija, koja dolazi odozgo, od Svevišnjega.

Treba imati na umu da Toma Čelanski navodi kako je Franjo svome Pravilu htio dodati riječi "Duh Sveti je generalni ministar Reda«, ali je s tim dodavanjem zakasnio, jer je Pravilo već bilo potvrđeno. Ovu tvrdnju 
potkrepljuje Nguyên-Van-Khan Norbert u svojoj knjizi Krist u misli svetoga Franje Asiškoga prema njegovim Spisima i dokazuje da duhovnost sv. Franje polazi od Duha Svetoga - prisutnoga u svijetu, u svim Božjim stvorenjima - pa je po Sinu usmjerena k Ocu (1989, 284). Time je rečeno da je poslušnost Duhu primarna i da se odnosi na sve članove Reda, Crkve i na sve ljude. Duh je apsolutno slobodan i apsolutno nov. Čovjek koji je otvoren i poslušan Duhu Svetome postaje slobodan i nov.

\section{Kristologija fra Matije Divkovića}

Nakon izložene kristologije sv. Franje potrebno je izložiti kristologiju fra Matije Divkovića, jer se u njoj najbolje zrcali duh bosanskih franjevaca, osobito Anđela Zvizdovića.

Utemeljitelj franjevačke - a time i bosanskohercegovačke - književnosti na narodnom jeziku bio je fra Matija Divković, autor prvih tiskanih knjiga na narodnom jeziku, koji je iz pastoralnih razloga stvarao zajednički jezik za sve vjernike. Divković je pisao bosančicom (bosanskom ćirilicom) i u tiskari Petra M. Bertana sam za svoje knjige lijevao slova i osmišljavao grafička rješenja. God. 1611. objavio je djela Nauk krstjanski i Sto čudesa te Besjede i tzv. mali Nauk, koji je do 1738. objavljen dvadesetak puta, i to u dvije varijante, opsežnoj i skraćenoj.

Divković se rodio 1563. (te je godine zaključen Tridentski sabor), a umro je 1631. U tom su se razdoblju vodili nemilosrdni ratovi među kršćanskim konfesijama: katolicima i protestantima. Tada je vrijedila deviza cuius regio euis religio (»čija regija njegova religija»). I Lutherova Reformacija (1517) i katolička Reformacija (nazvana protureformacijom) po mom sudu su više protureformacije nego reformacije, što znači da su više usmjerene jedna protiv druge, nego što su usmjerene na izvornu, evanđeosku formu života, na vita apostolica et evangelica. Vraćanjem na mjerodavnu formu života započinje reformacija kršćanstva, što je najjasnije pokazao sv. Franjo Asiški. Divković se u svojim djelima vraća apostolskoj i evanđeoskoj formi života, tj. Isusu Kristu i njegovim učenicima. On ni s kim ne ulazi spor: ni s protestantima, ni s pravoslavcima, ni s muslimanima. Divković pozitivno izlaže kršćanski nauk. Njegov je govor određen pozitivnom evanđeoskom logikom, koja izbjegava osuđivanje drugih. Ivana Mikulić je usporedila 
Divkovićev katekizam Nauk krstjanski s katekizmom Ivana Grličića Put nebeski i došla do uvida da je Divkovićev govor o vjeri i drugim aspektima ljudske svakidašnjice određen pozitivnom evanđeoskom logikom koja izbjegava osuđivanje drugih $(2017,49-71)$.

Divković poziva kršćane da najprije sude samima sebi: »Ne sudite da ne budete suđeni!« (Mt 7,1) On ističe da ima mnogo kršćana, ali je malo dobrih kršćana, jer su mnogi samo po imenu kršćani, ali ne i po djelu; za njega su kršćani oni koji Isusa Krista nasljeduju djelom, jer Divković - poput sv. Franje - želi gol nasljedovati gologa Krista (nudus nudum Christum sequi). Vrhunac kršćanskoga humanizma Divković nalazi u Matejevu Evanđelju (25,40: Ono što ste učinili jednom od ove moje najmanje braće, meni ste učinili!!), a osobito u Isusovoj ljubavi prema neprijateljima, jer Bog ljubi svoje neprijatelje, tj. grešnike.

U predgovoru Besjedama Divković ističe mir kao središnju ideju, jer u tom vremenu kršćani katolici i kršćani protestanti vode nemilosrdne i krvave ratove. On veli da je Isus Krist želio da njegovi učenici šire mir, to je želio i sv. Franjo, a to želi i on, »nedostojan sluga i brat vaš«. Bog je, po Divkoviću, svojim neprijateljima (grešnicima) poslao novoga Adama, Isukrsta, da uspostavi mir između Boga i čovjeka. Kao što Bog ljubi svoje neprijatelje, tako i pravi kršćani, po Divkoviću, trebaju ljubiti svoje neprijatelje. Mir između Boga i čovjeka pretpostavka je mira među ljudima i mira u čovjeku. Kršćanski put jest put samoponiženja, odricanja od svake moći (kenosis), jer je Isus došao gol i bos na ovaj svijet i gol umro na križu (Babić 2014, 391-426).

Na kraju sažimam osnovne misli Divkovićeve kristologije, o kojoj sam već pisao (Babić 2017, 113-127). Božja se ljubav kod Divkovića očituje kao samoponiznost. Bog je ponizio sebe da bi uzvisio (spasio) čovjeka. Isukrstova se ljubav također očituje kao samoponiznost: Isukrst je ponizio sebe i bio ponizan sve do smrti na križu. Bio je gol i ubog na početku svoga života, za vrijeme svoga života i na kraju svoga života. Nasuprot Isukrstu, stari čovjek Adam uzvisivao je sebe i bio je ponižen, jer u Evanđelju Isus kaže: Tko se uzvisuje bit će ponižen, a tko se ponizuje bit će uzvišen. Ono što se događa s čovjekom događa se s cijelim stvorenjem jer je kod Divkovića čovjek zastupnik cijeloga Božjeg stvorenja. Iz ljubavi kao samoponiznosti proizlazi bezuvjetna ljubav prema neprijatelju: Bog ljubi 
svoje neprijatelje (grešnike), Isukrst ljubi svoje neprijatelje. Dakle, kršćanin je onaj koji ljubi svoje neprijatelje. Ljubav je konkretno i praktično djelo, što znači da je kršćanin onaj koji djelom nasljeduje Isusa Krista. Otvorenost Isukrstovu Duhu, tj. Duhu Svetome omogućuje kršćanima da Isukrsta nasljeduju praktično. Duh Isukrstov koji stanuje u kršćanima pokreće ih na djelovanje, tj. na praktično nasljedovanje Isusa Krista.

O prisutnosti duha sv. Franje među bosanskim franjevcima, osobito kod fra Anđela Zvizdovića, pisali su nobelovac Ivo Andrić i Nikola Šop. U svojoj doktorskoj disertaciji pod naslovom Razvitak duhovnog života u Bosni pod uticajem turske vlasti Andrić opisuje dokle ide samoponiznost bosanskih franjevaca. On piše da su oni svoj rad obavljali u veoma teškim uvjetima, s iskrenim predanjem is najvećom požrtvovnošću. Težili su da koriste narodu i da ga vode ka boljem, što je jedna od njihovih najljepših osobina i jedna od njihovih najvećih zasluga. Cilj im je bio da služe spasenju duša. Zbog svoje spremnosti na žrtvu i ustrajnosti u dušobrižništvu, zbog svoga besprijekornog načina života i svoga moćnog utjecaja na vjernike mogu služiti kao svijetli primjer katoličkom duhovništvu i svećenstvu cijelog svijeta. Njihovo samoporicanje graniči s mučeništvom. Prilike su stvorile iz bosanskog franjevca jedan svojevrstan, poseban tip franjevca i svećenika ne samo unutar Franjevačkog reda nego i unutar sveukupnog duhovništva i svećenstva Katoličke Crkve. Taj svoj stav o bosanskim franjevcima Andrić je na umjetnički način obradio i razvio u svojim književnim djelima.

Kolika je bila moć ljubavi kao samoponiznosti kod bosanskih franjevaca, pokazuje veliki pisac Nikola Šop (rođen u bosanskom gradu Jajcu) u svojoj trodijelnoj poetsko-mističnoj drami pod naslovom Bosanska trilogija. U cijeloj drami Šop prikazuje samoponiznost bosanskog franjevca fra Anđela Zvizdovića (u drami nazvan Vranđeo), bosanskih franjevaca, zadnjeg bosanskog kralja Stjepana Tomaševića (u drami nazvan Štipan) i ostalih pripadnika Bosanskog kraljevstva. Bosna je prikazana kao zemlja samoponiznosti. U Bosni je sve maleno, počevši od malenog Isusa pa do malenih bosanskih crkava. Glavna svetkovina u Bosni je svetkovina sv. Ive Krstitelja, koja se slavi 24. lipnja svake godine u blizini Jajca, na kojoj se skupljaju hodočasnici iz cijele Bosne i na kojoj se događaju čuda dobrote, zahvaljujući Božjem Duhu koji je tu prisutan. 
Šop je u drami ocrtao obilježja rimske i turske moći, koje se uvećavaju pobjeđivanjem neprijatelja, i obilježja bosanske (franjevačke) nemoći: samoponiznost i vjeru u nepobjedivu moć dobrote i ljubavi. Šop ističe da je moć nemoćna pred onima koji ne prihvaćaju logiku moći, pred onima koji ne žele ubijati nego ljubiti. Moć može komunicirati s nemoći (s dobrotom) samo onda ako prestane biti moć, ako, dakle, prihvati logiku ljubavi. Šop zapravo želi reći da dobrota može obratiti svaku silu i moć, svaku vlast, samo ne može obratiti svetu vlast, tj. onu vlast koja samu sebe obožava, koja je sebe pretvorila u božanstvo, u idola.

Sredinom 18. stoljeća, ističe poznati turkolog Vjeran Kursar, bosanski su franjevci primili i službeno priznanje svoga posebnoga položaja na simboličan način. God. 1758. gvardijani fojničkoga i kreševskoga samostana, zajedno s Benićem, predali su bosanskom veziru Mehmed-paši Kukavici u Travniku $d \check{z} u l u s$, porez koji se daje novoimenovanom veziru. Tada su franjevački predstavnici bili zaogrnuti tzv. binjišima (tur. biniş), počasnom odjećom, crvenim ogrtačem od čohe, kojim je bio zaogrnut i fra Anđeo Zvizdović 1463, kad je primio ahdnamu od Mehmeda Osvajača. Ta se ceremonija, prema Benićevoj kronici, ponovila više puta prilikom stupanja u službu novih vezira. Ona je imala političko značenje, jer je uključivala franjevačke predstavnike u osmanski državno-upravni sustav. Iako franjevci osmansku državu nisu priznavali kao svoju, ipak su bili kritički lojalni, pa su im osmanske vlasti, 300 godina nakon legendarnoga susreta fra Anđela Zvizdovića i Mehmeda Osvajača, ponovili tu ceremoniju davanja plašta, što znači da su time primili franjevce u osmansku službu (Kursar 2017, 449-475). Bosanski su, dakle, veziri odali priznanje bosanskim franjevcima. Iz toga će kasnije veliki pisac i pjesnik Nikola Šop izvesti u svojoj Bosanskoj trilogiji da su bosanski franjevci evanđeoskom logikom dobrote mogli obratiti svaku vlasti, pa i osmansku, ali ne i svetu vlast, koja je samu sebe apsolutizirala.

U pričama o svome zavičaju Šop opisuje katakombe u Jajcu i kaže (parafraziram): gdje god postoje silnici, postoje katakombe. On uvjerljivo dokazuje da svaki silnik, kada drugome oduzima slobodu, sam je izgubi u istom trenutku: »Katakombe. Gle, i ovaj mali gradić ih ima. Dakle, u tim zidinama, u tim kamenitim gnijezdima nad vodopadom, živjeli su silnici, dobro utvrđeni; jer gdje god je bilo silnika, tu su i katakombe. Gledajući prezrivo kroz prozore svojih kula, kroz okna kovana u rešetke, oni su sami 
sebe učinili sužnjima; jer tko oduzme slobodu drugima, i sam je izgubi u istome trenutku. Katakombe su kao rijeka ponornica. Spriječena u svom prirodnom toku po zemlji, ona zapjenjena i ljutita, razbija dno svoga korita, razriva utrobu zemlje, bijesno krči put i najzad nađe ušće u beskrajnom moru, koje nema granica, ni gospodara. Katakombe su podrovale krvave temelje silničkih kula." (Šop 2006, 98-99) Iz navedenoga slijedi da je sloboda za Šopa nedjeljiva jer je nemoguće biti slobodan na tuđu štetu: ili smo svi slobodni, ili nije nitko. Jednako su udaljeni od slobode i tlačitelji i potlačeni, pobjednici i pobijeđeni.

\section{Istovjetnost dviju kristologija: Franjine i Zvizdovićeve}

Divkovićeva je kristologija istovjetna s kristologijom Franje Asiškoga. On ima viziju života kakvu ima i sv. Franjo: za obojicu je mjerodavna Isusova forma života (vita apostolica et evangelica, apostolski i evanđeoski život Isusa i njegovih učenika). Naime, Divković tvrdi da Isukrsta treba nasljedovati srcem (vjerom koja izlazi iz srca) i djelima. On najoštrije kritizira kršćane koji su kršćani samo po imenu, a ne po djelima. Kršćanin je onaj koji ljubi neprijatelja kako ga je Isukrst ljubio i koji čini dobro svakome, a to znači i onima koji njemu čine zlo i koji ga progone i proklinju. I Divković kao i sv. Franjo shvaća duboki smisao rečenice Nudus nudum Christi sequi: Isukrstova ljubav ima oblik samoponiznosti/kenoze (Fil 2,7). I Franjo i Divković ističu poniznost, nasljedovanje Isusa Krista u poniznosti, jer biti manji (minor) je proces samoumanjivanja i samoponiženja. Treba podnositi sve nevolje i nepravde dobrovoljno. Za Divkovića su sva Božja stvorenja dobra i lijepa i Bogu draga; kod njega je riječ o spasenju cjelokupnoga Božjeg stvorenja.

Divković - kao i Franjo - ostaje vjeran evanđeoskoj logici dobrote, koja ne govori ni protiv koga, nego čini dobro svima (i zlima). On navodi Isukrstove riječi: »Ne sudite da ne budete suđeni!« (Mt 7,1) i »Jer kad bismo sami sebe sudili, ne bismo bili suđeni« (1 Kor 11,31). U predgovoru Nauku krstjanskome Divković poziva svakoga kršćanina da sudi sam sebi i da se izmjeri glavnim mjerilom koje se zove Isus Krist. On stalno ponavlja da je vrhunac Isusova siromaštva goloća na početku i na kraju Isusova života, što je sv. Franjo praktično nasljedovao. Siromaštvo Divković shvaća kao slobodu, jer posjedovanje materijalnih dobara priječi ljubav prema Bogu 
i bližnjemu, a time ponavlja Franjine riječi. Sloboda je, dakle, oslobođenost od egoizma, od samouzvisivanja, od robovanja samome sebi. Iz velike slobode nastaje velika ljubav kao samoponiznost. Za Divkovića je Isukrstov zakon - zakon izvrsne (izvrstite) slobode. Biti vjeran Božjem Duhu - a bit Duha jest slobode - znači biti vjeran Duhu slobode. Taj je Duh je zapravo general Franjevačkoga reda.

I sv. Franjo i fra Matija Divković jasno ističu da treba pozitivno misliti, govoriti i djelovati, pozitivno uzvraćati na tuđu negativnost, a to znači da treba ljubiti svoga neprijatelja. Svevišnji ljubi svoje neprijatelje kao što je i Isus Krist ljubio svoje neprijatelje. Prema onima koji se prema nama odnose najnegativnije trebamo se odnositi najpozitivnije. Prema najvećim neprijateljima trebamo se odnositi kao prema najvećim prijateljima. Samo je tako negativnost moguće pretvoriti u pozitivnost, tj. prijeći iz paradigme nasilja u paradigmu nenasilja. 


\section{Reference}

Andrić, Ivo. 1982. Razvitak duhovnog života u Bosni pod uticajem turske vlasti. Sveske Zadužbine Ivo Andrić 1: 124-156.

Babić, Mile. 2014. Divković kao reformator. Matija Divković $i$ kultura pisane riječi. Sarajevo: Franjevačka teologija \& Kulturno-povijesni institut Bosne Srebrene: 391-426.

- - -. 2017. Divkovićeva kristologija u Besjedama. Matija Divković i kultura pisane riječi II. Sarajevo-Zagreb: Kulturno-povijesni institut Bosne Srebrene \& Hrvatska sveučilišna naklada: 113-127.

- - - 2019. Nasilje idola. Sarajevo: University Press.

Berman, Harold J. 1995. Recht und Revolution. Frankfurt am Maim: Suhrkamp.

Čelanski, Toma. 1995. Vita secunda. Fontes Franciscani. Assisi: Edizioni Porziuncola.

Deklaracija o ljudskom bratstvu za mir u svijetu i zajednički život, Katolička tiskovna agencija Biskupske konferencije Bosne i Hercegovine, 1-4.

Frugoni, Chiara. 2001. Vita di un uomo: Francesco d'Assisi, Torino: Einaudi.

Jeusset, Gwenolé. 2008. Sveti Franjo $i$ sultan. Sarajevo: Svjetlo riječi.

Kammerer, Peter, Ekkehart Krippendorff in Narr Wolf-Dieter. 2008. Franz von Assisi - Zeitgenosse für eine andere Politik. Düsseldorf: Patmos.
Kursar, Vjeran. 2017. Živjeti krstjanski pod turskim gospodstvom. Osmansko carstvo u djelima bosanskih franjevaca 18 . stoljeća. Matija Divković i kultura pisane riječi II. Sarajevo-Zagreb: Kulturnopovijesni institut Bosne Srebrene \& Hrvatska sveučilišna naklada: 449-475.

Kuster, Niklaus. 2009. Franziskus. Rebell und Heiliger. Freiburg-Basel-Wien: Herder.

Le Goff, Jacques. 2010. Sveti Franjo Asiški. Zagreb: Demetra.

Manselli, Raul. 2011. Sveti Franjo Asiški. Sarajevo: Svjetlo riječi.

Mikulić, Ivana. 2017. Divković i Grličić: počeci bosanske i slavonske katekizamske književnosti. Matija Divković i kultura pisane riječi II, SarajevoZagreb: Hrvatska sveučilišna naklada \& Kulturno-povijesni institut Bosne Srebrene: 49-71.

Norbert, Nguyên-Van-Khan. 1989. Le Christ dans la pensée de saint François d'Assise d'aprés ses Écrits. Paris: Éditions Franciscaines.

Rohr, Richard. 2015. Die Liebe leben. Was Franz von Assisi anders machte. Freiburg-Basel-Wien: Herder.

Spisi svetoga Franje i svete Klare. 2005. Mostar: FRAM-ZIRAL.

Šop, Nikola. 1980. Bosanska trilogija. Sarajevo: Veselin Masleša.

- - -. 2006. Proze. Sarajevo: Matica hrvatska - HKD Napredak. 